\title{
Effects of Tractorization and Organic Manure on Physical Properties of Sandy Loam Soil in
} Abeokuta, Nigeria

\author{
P. O. O. Dada ${ }^{1 *}$, J. J. Musa ${ }^{2}$, O. O. Olla ${ }^{3}$, J. O. Ohu' ${ }^{4}$ J. K. Adewumi ${ }^{1}$
}

${ }^{1}$ Department of Agricultural and Bioresources Engineering, Federal University of Agriculture, Abeokuta, Nigeria. ${ }^{2}$ Department of Agricultural and Bioresources Engineering. Federal University of Technology, Minna, Nigeria.

${ }^{3}$ National Centre for Agricultural Mechanization, Ilorin. Nigeria.

${ }^{4}$ Department of Agricultural and Bioresources Engineering. University of Maiduguri, Maiduguri, Nigeria.

ABSTRACT: Soil compaction has effect on soil physical properties which could affect crop growth and yield. This study was conducted to determine the influence of incorporating organic materials and load application (tractorization) on the physical properties of sandy loamy soil in Abeokuta, Ogun State, Nigeria. Organic materials were cow dung, poultry and swine manure. Application rates of organic manures were 0 (control), 5 and 10 tonnes per hectare. Forty-five plots measuring 5 by $3 \mathrm{~m}$ were established in a complete randomized block experimental design with three replications making a total of 135 plots. Load application was done using an MF 435 tractor coupled with a 20-disc harrow at 0 (control), 5, 10, 15 and 20 passes. Penetration resistance, bulk density, gravimetric moisture content and porosity were determined using standard procedures. Penetrometer resistance at these passes were 392.2, 293.3, 285.0, 302.0 and $224.9 \mathrm{kPa}$ respectively with significant differences between treatments $(\mathrm{P} \leq 0.05)$. Mean bulk density for the passes were $1.21,1.26,1.31,1.27$ and $1.29 \mathrm{~g} / \mathrm{cm}^{3}$ respectively and bulk density increased with tractor passes. The effect of tractor passes, and manure incorporation rate did not have any significant effect on gravimetric moisture content. Poultry manure increased bulk density and penetrometer resistance on plots than swine manure and cow dung hence poultry manure at $10 \mathrm{t} / \mathrm{ha}$ can be incorporated on a sandy loam soil to enhance soil fertility and sustainability.

KEYWORDS: Tractorization, organic manure, sandy loam, penetration resistance, bulk density

\section{INTRODUCTION}

Soil compaction is a process that increases soil density by decreasing the volume of air in a soil. It is generally the densification of soils through the application of mechanical energy (tractorization) which results in pore space reduction (Ohu et al., 2011). Soils that are compacted can reduce infiltration rate, restrict root penetration and growth through the soil and affects the soil structure. Several researchers have concluded that soil compaction could be caused by farm machinery, grazing animals and other load application mechanisms which lead to increased bulk density, low porosity and low rate of infiltration into soils (Hamza and Anderson, 2005; Raper and Kirby, 2006, Castellano and Valone (2007). The negative effects of soil compaction cannot be ignored considering seedling emergence and yield of crops (Radford et al., 2000) through restricted root growth and consequently, nutrient uptake. Mamman and Ohu (1998) stated that soil compaction could be advantageous for seed and soil particle contact but when it becomes severe, the soil strength is increased.

In tillage operations, soil compaction has been shown to affect crop production by the great reduction in soil porosity which invariably causes reduction in soil aeration and hydraulic conductivity (Hakansson and Lipiec, 2000).
Defossez and Richards, (2002) highlighted the damage compaction does to the structure of tilled soils and subsoils such as altering the structure of cultivated soils by rearrangement of the clods which invariably affects crop production and soil workability. Other negative effects of compaction are reduced infiltration, increased runoff risks through blockage of soil pores which is dependent on the soil type (Gupta et al., 1989). Seedling emergence and root growth are also affected by compaction (Durr and Aubertot, 2000).

Many agricultural soils have been drastically affected by soil compaction and this has reduced crop production in many farmlands in Nigeria. Physical changes as a result of soil compaction has also changed the microhabitats for soil microorganisms by inhibiting their ability to recycle soil nutrients and reducing microbial activity (Pengthamkeerati et al., 2005, 2006). Compacted soils must be restored to boost crop production and improve their structural properties.

Soil organic amendments have been used to remediate soil compaction. Reicosky, (2002) used bulky organic materials to reduce soil bulk density and compactibility through increasing soil porosity, rate of infiltration and water holding capacity of the soil which lead to better aeration and 
moisture for microorganisms and crops. A similar study was conducted by Agele, (2000) where the reclamation of an erosion simulated soil was done with the use of farmyard manure and NPK fertilizer. In the study by Salako et al, (2007) poultry manure was a better amendment than NPK in the restoration of an artificially degraded soil. The poultry manure applied at $10 \mathrm{t} \mathrm{ha}^{-1}$, improved shoot and root mass density of maize crop, nutrient uptake and maize grain yield and this could be as a result of the ability of organic manures to aid infiltration and reduce bulk density in soils.

Few studies are available in the south western part of Nigeria to guide farmers on the use of organic materials and the frequent use of tractor for cultivation practices especially on soils with sandy loamy nature which are common in many agricultural lands in the Southwest of Nigeria. There is the need to make good use of such soils and improve their fertility for improved crop yields. The objective of this study is to evaluate the effect of organic manure incorporation and trafficability on the physical properties of a sandy loamy soil in Abeokuta, Southwestern Nigeria.

\section{MATERIALS AND METHODS}

\section{A. Experimental Setup}

The study site was located in the Federal University of Agriculture, Abeokuta in Ogun State Southwest Nigeria (Latitude $7^{\circ} 14^{\prime}$ North and Longitude $3^{\circ} 25^{\prime}$ East). The average annual rainfall is $1200 \mathrm{~mm}$ with a mean daily temperature of $25^{\circ} \mathrm{C}$. A land area measuring 100 by $120 \mathrm{~m}$ was cleared manually with simple hand tools and stumps and small roots removed. Three main plots were established and divided into subplots of sizes $3 \mathrm{~m}$ by $5 \mathrm{~m}$ with $3 \mathrm{~m}$ buffer for tractor turnings. A total of 45 subplots were established in the first replication making a total of 135 subplots for the three replications. The study was carried out in the month of September just before the onset of the dry season. The randomised complete block design was used for experimental setup to cater for variations that may arise on the field as shown in Figure 1.

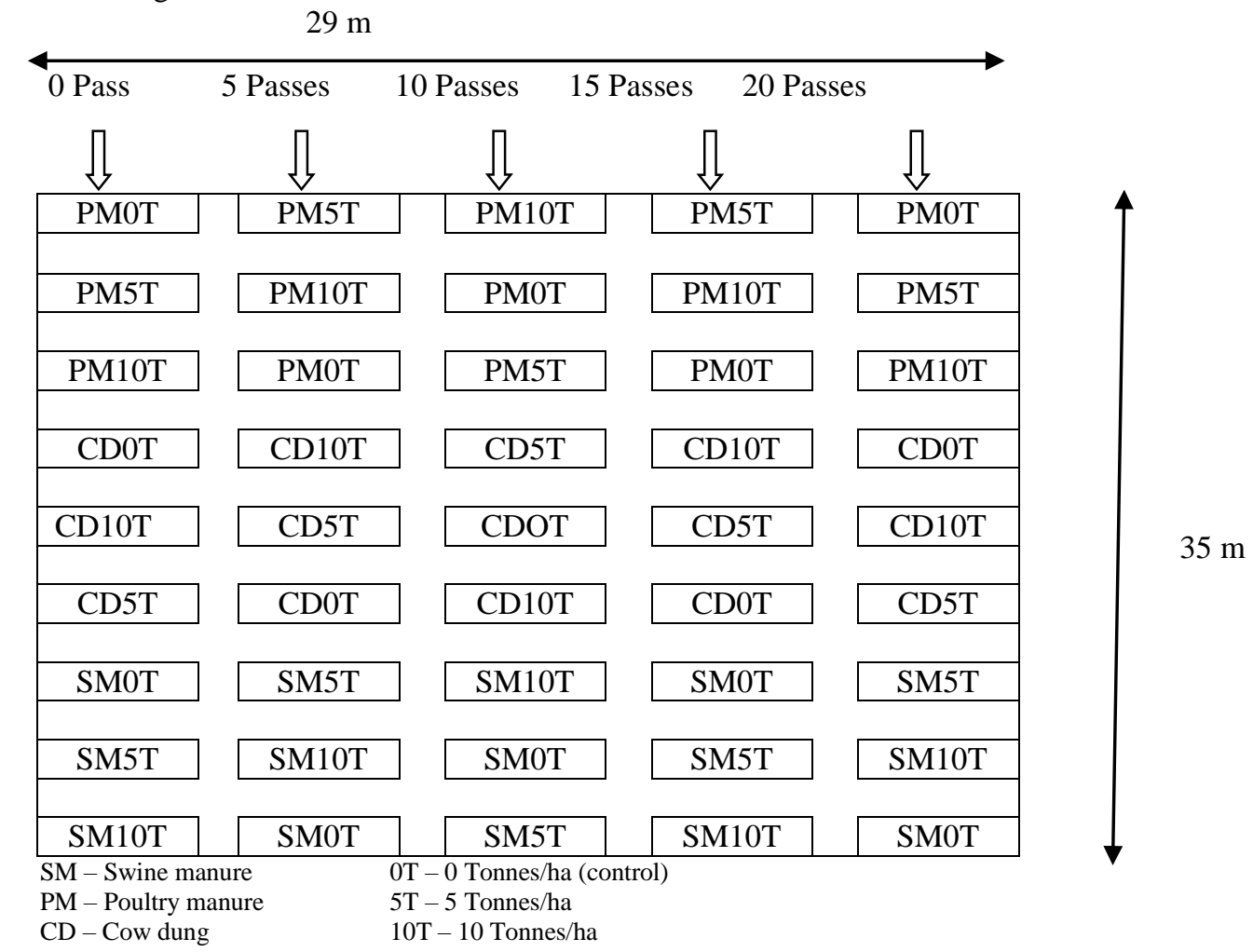

Figure 1: Experimental plot (Rep 1).

\section{B. Manure Incorporation}

Poultry manure, cow dung and swine manure (organic manure treatments) were collected from the University farms and applied at the rate of 0 (control), 5 and 10 tonnes/ha representing 0 (control), 0.5 and $1 \mathrm{~kg} / \mathrm{m}^{2}$ ) on the plots. Manure incorporation was done on all subplots by broadcasting manually on the surface of the soil. After the manure was spread on the plots, grid sampling were taken at randomly selected locations across the plots to determine the percentage of the surface soil that was covered with manure. The sampling tool was a constructed wooden grid measuring $61 \times 61 \mathrm{~cm}$ with strings stretched every $5 \mathrm{~cm}$ along each side to form a grid. Surface coverage was measured by determining the number of places where manure lay under string intersections. Over $90 \%$ coverage by manure on the subplots was achieved in this study. After two weeks of manure application on field, tractorization was achieved by a MF-435 four wheel drive tractor coupled to a light duty mounted disc harrow (2-gang) and run at 0 (control), 5, 10, 15 and 20 passes. The tractor was operated at an average speed of $6 \mathrm{~km} / \mathrm{hr}$. Increased number of passes were used to represent the effects of continuous use of tractor for harrowing operation on the same piece of land.

\section{Parameters Investigated}

\section{1.) Determination of soil physical properties}

i.) Soil moisture content: The gravimetric moisture content of each subplot was determined by using oven drying 
method. Soil samples were collected before and after tractorization using steel core samplers of $7 \mathrm{~cm}$ diameter and depth $10 \mathrm{~cm}$ at soil depths of $0-10$ and $10-20 \mathrm{~cm}$ for the determination of soil moisture content towards the end of September. The collected soil samples were stored in cellophane bags, weighed and oven dried at $105{ }^{\circ} \mathrm{C}$ until constant weight was achieved. Gravimetric moisture content was determined by the equation:

$$
\theta g=\frac{M t-M s}{M s}=\frac{M w}{M s}
$$

where $\Theta g$ is gravimetric moisture content $(\%)$

$M t$ is total mass of wet soil $(\mathrm{g})$

$M s$ is mass of dry soil ( $\mathrm{g})$

$M w$ is mass of water $(\mathrm{g})$

ii.) Soil textural Class: Collected soil samples were ground to pass through a $2 \mathrm{~mm}$ sieve mounted on an electric sieve shaker and thereafter air dried for two days before determination of particle size density. The soil textural class which is an indication of the percentage of sand, silt and clay in the soil was determined by particle size distribution using the hydrometer method as stated by Gee and Or, (2002) and the soil samples were classified according to the United States Department of Agriculture (USDA) soil texture classification.

iii.) Soil bulk density: This was investigated both before and after the tractor passed on each plot to access the level of soil compaction due to tractor passes. Samples were taken from each plot at depths of $0-10$ and $10-20 \mathrm{~cm}$ using cylindrical cores (Blake and Hartge, 1986) with dimension 7 $\mathrm{cm}$ diameter and $10 \mathrm{~cm}$ height. Each of the samples were transferred into a moisture can, weighed and oven dried at $105^{\circ} \mathrm{C}$ until constant weight was achieved. The samples were reweighed to determine the mass of dry soil. Mathematically, bulk density was calculated using the relation:

$$
B d=\frac{W_{d r y}}{V o l}
$$

where:

$B d=$ dry bulk density $\left(\mathrm{g} \mathrm{cm}^{-3}\right)$

$W_{d r y}=$ weight of the dried soil sample $(\mathrm{g})$

$V o l=$ total volume of the soil core sampler $\left(\mathrm{cm}^{3}\right)=\pi \mathrm{r}^{2} \mathrm{~h}$. where $\mathrm{r}$ is radius of soil core and $\mathrm{h}$ is the height $(\mathrm{cm})$

iv.) Soil penetrometer resistance $(\mathrm{kPa})$ was investigated using a hand pushed cone penetrometer (ASAE, 2004) of base area $133 \mathrm{~mm}^{2}$ and cone diameter of $13 \mathrm{~mm}$. Measurements were taken at depths of $0-30 \mathrm{~cm}$ on four different locations on each of the subplots. Mean values were determined by for each subplot.

v.) Soil Porosity: This was determined from bulk density values obtained using the standard particle size density of $2.65 \mathrm{~g} / \mathrm{cm}^{3}$. Porosity $(T p)$ was determined using the relation:

$$
T p=\left(1-\frac{\text { Bulk } \cdot \text { density }}{\text { Particle } \cdot \text { density }}\right) \times 100
$$

2.) Data analysis: The raw data emanating from this research work was subjected to Analysis of Variance (ANOVA). Mean differences were found using the Duncan Multiple Range Test at 0.05 level of significance. GenStat statistical software (version 2016) was used.

\section{RESULTS AND DISCUSSION}

\section{A. Mean Soil Bulk Density}

The mean soil bulk density for the whole field was 1.27 $\mathrm{g} \mathrm{cm}^{-3}$ but values ranged from 0.75 to $1.42 \mathrm{~g} \mathrm{~cm}^{-3}$. Mean bulk density for $0,5,10,15$ and 20 passes were $1.21,1.26,1.31$, 1.27 and $1.29 \mathrm{~g} \mathrm{~cm}^{-3}$ respectively. The low bulk density values give an indication of the loose and sandy nature of the soil. It also gives an indication of higher volume of air in the macropores. In a study by Alletto and Coquet (2009), bulk density could vary temporally within a season because of factors such as volume and intensity of precipitation, temperature of the soil and crop type. Tractor pass had significant effect on the soil bulk density as observed on plots $(\mathrm{P} \leq 0.05)$.

Significant differences were observed between the 0 and 10 passes, 0 and 15 passes and 0 and 20 passes but there was no significant difference between the 0 and 5 passes (Table 1). This could be attributed to the minimal number of passes and fact that the number of runs by machinery had not increased. The result clearly indicates that bulk density increases as the tractor passes increases. Similar results were reported by (Ogunjirin and Kamal, 1999; Manuwa et al., 2011) where repeated passes of machinery also increased bulk density. The effect of manure incorporation rate on mean soil bulk density was also significant $(\mathrm{P} \leq 0.05)$. As the incorporation rate of poultry manure and swine manure were increased, there was an increase in bulk density on the plots with respect to tractor passes though the effect was not significant with respect to cow dung (Table 1). This could be attributed to the good binding properties of poultry manure and swine manure as against cow dung.

Organic manure such as crop residues tend to have a low density as reported by Ohu et al., (2001) and they tend to reduce the effect of compaction but in this study there was an increase in bulk density especially on poultry manured plots. The effect of the interaction between manure incorporation rate and tractor passes was not significant $(\mathrm{P} \leq 0.05)$ with respect to bulk density. The low bulk density observed in the plots resulted in very high porosity with values well over $50 \%$ confirming the loose nature of the soil. 
Table 1: Mean Soil Bulk Density $\left(\mathrm{g} \mathrm{cm}^{-3}\right)$ due to tractorization and manure incorporation rate.

\begin{tabular}{|c|c|c|c|c|c|c|c|c|c|}
\hline & \multicolumn{3}{|c|}{$\begin{array}{c}\text { Poultry Manure } \\
\text { incorporation Rate (t/ha) }\end{array}$} & \multicolumn{3}{|c|}{$\begin{array}{c}\text { Cow dung incorporation } \\
\text { Rate (t/ha) }\end{array}$} & \multicolumn{3}{|c|}{$\begin{array}{c}\text { Swine Manure } \\
\text { incorporation Rate (t/ha) }\end{array}$} \\
\hline & 0 & 5 & 10 & 0 & 5 & 10 & 0 & 5 & 10 \\
\hline & \multicolumn{3}{|c|}{$\mathrm{g} \mathrm{cm}^{-3}$} & \multicolumn{3}{|c|}{$\mathrm{g} \mathrm{cm}^{-3}$} & \multicolumn{3}{|c|}{$\mathrm{g} \mathrm{cm}^{-3}$} \\
\hline 0 Pass & 1.23 & 1.27 & 1.29 & 1.31 & 0.75 & 1.23 & 1.26 & 1.32 & 1.25 \\
\hline 5 Passes & 1.31 & 1.29 & 1.24 & 1.20 & 1.25 & 1.26 & 1.26 & 1.26 & 1.31 \\
\hline 10 Passes & 1.23 & 1.30 & 1.22 & 1.30 & 1.36 & 1.40 & 1.32 & 1.37 & 1.33 \\
\hline 15 Passes & 1.33 & 1.30 & 1.27 & 1.33 & 1.24 & 1.20 & 1.29 & 1.25 & 1.25 \\
\hline 20 Passes & 1.30 & 1.31 & 1.29 & 1.31 & 1.20 & 1.33 & 1.42 & 1.26 & 1.26 \\
\hline \multicolumn{10}{|c|}{ LSD P $\leq 0.05$} \\
\hline \multicolumn{10}{|c|}{ Manure $=0.05$} \\
\hline \multicolumn{10}{|c|}{ Tractorization $=0.03$} \\
\hline \multicolumn{10}{|c|}{ Manure $\mathrm{x}$ Tractorization $=0.10$} \\
\hline
\end{tabular}

\section{B. Mean Moisture Content}

Moisture content was generally low on the field with values ranging from 0.62 to $1.25 \%$. This may be due to the dry and loose state of the soil when the experiment was performed. At $0,5,10,15$ and 20 passes, moisture content were $1.02,1.04,1.01,0.89$ and $0.73 \%$ respectively at the 0 $20 \mathrm{~cm}$ depth. Field observations show that at deeper depths, moisture content could increase, tractor passes did not have any effect on the moisture content $(\mathrm{P} \leq 0.05)$ and the manure incorporation rate did not have any effect on the moisture content (Table 2) but it was observed that, moisture content increased when incorporation rate of cow dung was increased from 5 to $10 \mathrm{tha}^{-1}$ and this was due to the fact that the organic manure increased the water holding capacity of the soil and this is in line with Chang-An et al., (2013). The interaction between manure and tractor passes was not significant on the field. This could be as a result of the dry state of the soil and the fact that moisture content of the soil depends on the climatic condition of the environment and the sandy loamy nature of soil observed on the entire field.

Table 2: Mean Moisture Content (\%) as influenced by tractor pass and manure incorporation rate.

\begin{tabular}{|c|c|c|c|c|c|c|c|c|c|}
\hline & \multicolumn{3}{|c|}{$\begin{array}{c}\text { Poultry Manure incorporation } \\
\text { rate }\end{array}$} & \multicolumn{3}{|c|}{$\begin{array}{l}\text { Cow dung incorporation } \\
\text { rate }\end{array}$} & \multicolumn{3}{|c|}{$\begin{array}{c}\text { Swine Manure } \\
\text { incorporation rate }\end{array}$} \\
\hline & 0 & 5 & 10 & 0 & 5 & 10 & 0 & 5 & 10 \\
\hline 0 Pass & 0.71 & 0.94 & 1.25 & 1.28 & 0.63 & 1.25 & 1.24 & 1.05 & 0.90 \\
\hline 5 Passes & 0.96 & 1.25 & 0.65 & 1.24 & 0.71 & 1.31 & 1.23 & 1.02 & 1.04 \\
\hline 10 Passes & 1.16 & 1.12 & 1.20 & 1.23 & 0.66 & 1.01 & 0.77 & 0.74 & 1.21 \\
\hline 15 Passes & 1.18 & 0.77 & 0.99 & 1.06 & 0.68 & 0.73 & 0.68 & 0.76 & 1.14 \\
\hline 20 Passes & 0.83 & 0.65 & 0.64 & 0.62 & 0.66 & 0.99 & 0.63 & 0.61 & 0.93 \\
\hline $\begin{array}{l}\text { LSD } \mathrm{P} \leq 0 . \\
\text { Manure = } \\
\text { Tractoriza } \\
\text { Manure } \mathrm{x}\end{array}$ & tion $=$ & & & & & & & & \\
\hline
\end{tabular}

\section{Penetration Resistance}

Penetration resistance on soil treated with poultry manure cow dung and swine manure plots at 0 (control), 5 and 10 t/ha were 432.6, 398.4, 330.7, 334.7, 432.0, 396.7 and 409.3, 439.4, $356.2 \mathrm{kPa}$, respectively (Table 3). At the control plots which represents the original state of the plots before tractorization, the penetration resistance values on the control plots were higher compared to plots subjected to tractorization and this is as a result of the sandy state of the soil in the location. The harrowing of the soil loosened the soil significantly and reduced the penetration resistance.
Significant differences were observed in all the treatments with respect to tractor pass. It was observed that as tractor passes increases, the penetrometer resistance of the soil decreased further revealing the level of increased pulverization of the sandy loam soil by the harrow at the 20 $\mathrm{cm}$ depth. Penetration resistance was least at 20 passes of the tractor and harrow with value $224.9 \mathrm{kPa}$ (Table 3). Mean penetrometer resistance for cow dunged, swine manured and poultry manured plots were $306.6,309.1$ and $282.6 \mathrm{kPa}$ respectively. This clearly reveals that poultry manure was a better amendment in reducing penetration resistance of the

Table 3: Penetration Resistance as influenced by tractorization and manure incorporation rate.

\begin{tabular}{|c|c|c|c|c|c|c|c|c|c|}
\hline & \multicolumn{3}{|c|}{$\begin{array}{l}\text { Poultry Manure incorporation rate } \\
\qquad(\mathrm{t} / \mathrm{ha})\end{array}$} & \multicolumn{3}{|c|}{$\begin{array}{l}\text { Cow dung incorporation rate } \\
(\mathrm{t} / \mathrm{ha})\end{array}$} & \multicolumn{3}{|c|}{$\begin{array}{l}\text { Swine Manure incorporation } \\
\text { rate }(\mathrm{t} / \mathrm{ha})\end{array}$} \\
\hline & 0 & 5 & 10 & 0 & 5 & 10 & 0 & 5 & 10 \\
\hline & \multicolumn{3}{|c|}{$(\mathrm{kPa})$} & \multicolumn{3}{|c|}{$(\mathrm{kPa})$} & \multicolumn{3}{|c|}{$(\mathrm{kPa})$} \\
\hline 0 Pass & 432.6 & 398.4 & 330.7 & 334.7 & 432.0 & 396.7 & 409.3 & 439.4 & 356.2 \\
\hline 5 Passes & 294.9 & 249.9 & 242.7 & 299.3 & 294.5 & 306.7 & 299.6 & 324.0 & 325.5 \\
\hline 10 Passes & 292.3 & 258.7 & 278.0 & 314.3 & 285.2 & 250.5 & 325.0 & 290.6 & 270.2 \\
\hline 15 Passes & 225.7 & 254.5 & 245.2 & 321.0 & 353.5 & 325.5 & 297.1 & 332.0 & 363.3 \\
\hline 20 Passes & 257.3 & 270.8 & 207.3 & 210.2 & 248.6 & 225.9 & 203.0 & 195.7 & 204.8 \\
\hline \multicolumn{10}{|c|}{$\begin{array}{l}\text { LSD } \mathrm{P} \leq 0.05 \\
\text { Manure }=12.38 \\
\text { Tractorization }=9.23 \\
\text { Manure } \mathrm{x} \text { Tractorization }=27.68\end{array}$} \\
\hline
\end{tabular}


soil than the other organic amendments. Similar results by researchers have reiterated the effect of poultry manure in reducing soil strength and improving crop yield on degraded soils. (Salako et al., 2007).

\section{CONCLUSION}

The study considered the effect of tractorization and manure incorporation rate on bulk density, penetration resistance, moisture content and porosity on a sandy loam soil in Abeokuta, southwest Nigeria. This study showed that, bulk density values showed no significant differences as a result of tractorization at the $0-20 \mathrm{~cm}$ depth and, low values were observed in all the plots with high porosity. It was also observed that, poultry manure helped to increase the bulk density and water holding capacity of the sandy loamy soil in most of the treatments significantly. Due to the dry moisture condition of the soil and the sandy nature, moisture content was not affected by tractorization and manure incorporation rate. Penetrometer resistance which is an indication of the soil strength reduced as tractor passes increased in all the plots due to the sandy nature of the soil. Poultry manure was a better amendment in reducing penetration resistance compared to the other organic manures studied.

\section{ACKNOWLEDGEMENTS}

The authors are grateful to the Dean, College of Engineering of the Federal University of Agriculture, Abeokuta for releasing the portion of land used for this study. Also, gratitude to the tractor operators and students who assisted in setting up the plots.

\section{REFERENCES}

Agele S. O. (2000). Effects of animal manure and NPK fertilizer on simulated erosion and maize yield. International Journal of Environmental Education Information 19:131138.

Alletto, L. and Coquet, Y. (2009). Temporal and spatial variability of soil bulk density and near-saturated hydraulic conductivity under two contrasted tillage management systems. Geoderma 152:85-94.

ASAE Standards, 49th Ed. (2004). S313.3. Soil cone penetrometer. St. Joseph, Mich.: ASAE.

Blake, G. R. and Hartge, K. H. (1986). Bulk density. In: A. Klute (Ed.) Methods of soil analysis. Part 1. Physical and mineralogical methods. $2^{\text {nd }}$ Edition. American Society of Agronomy, Madison, Winscosin, 363-375.

Castellano, M. J. and Valone, T. J. (2007). Livestock, soil compaction and water infiltration rate: Evaluating a potential desertification recovery mechanism. Journal of Arid Environments71 (1):97-108.

Chang-An, L.; L. Feng-Rui; Z. Li-Min; Z. Rong-He; Yi-Jia; L. Shi-Ling; W. Li-Jun; H. M. S. Kadambot and L. Feng-Min. (2013). Effect of organic manure and fertilizer on soil water and crop yields in newly-built terraces with loess soils in a semi-arid environment. Agricultural Waste Management. Vol. 117:123-132.

Defossez, P. and Richard, G. (2002). Models of soil compaction due to traffic and their evaluation. Soil Tillage Research 67:41-64.

Durr, C. and Aubertot, J. N. (2000). Emergence of seedling of sugar beet (Beta vulgaris L.) as affected by aggregate size, roughness and position of aggregates in the seedbed. Plant Soil 219:211-220.

Gee, G. W. and Or, D. (2002). Particle size analysis. In J. H. Dane and G.C. Topp.(Ed). Methods of Soil Analysis. Part 4, Physical Methods. Soil Society America Book Series.255-295.

Gupta, S. C.; A. Hadas and R. L. Schafer. (1989). Modelling soil mechanical behaviour during compaction. In: Larson, W.E., Blake, G.R., Allmaras, R.R., Voorhees, W.B., and Gupta, S.C.(Eds.), Mechanics and Related Processes in Structured Agricultural Soils. NATON ASI Series E, Appl. Sci. 172. Kluwer Academic Publishers, Dordrecht, 137-152.

Hakansson, I. and Lipiec, J. (2000). A review of the usefulness of relative bulk density values in studies of soil structure and compaction. Soil Tillage Research 53:71-85.

Hamza, M. A. and Anderson, W. K. (2005). Soil compaction in cropping system. A review of the nature, causes and possible solution. Soil Tillage Research 82:121145 .

Mamman, E. and Ohu, J. O. (1998). The effect of tractor traffic on air permeability and millet production in a sandy loam soil in Nigeria. Ife Journal of Technology 81:17 .

Manuwa, S. I.; A. Adesina and B. F. Olajolo. (2011). Evaluation of soil compaction induced by repeated passes of rubber tracked excavator in sandy clay soil. Proceedings of the Nigerian Branch of International Soil Tillage Research Organisation ISTRO. $-21^{\text {st }}-24^{\text {th }}$ February, 2011. 80-89.

Ogunjirin, O. A. and Kamal, A. R. (1999). Effect of tyre inflation pressure and speed of operation on tractor tractive performance during tillage operation. Proceeding of Nigerian Institution of Agricultural Engineers (NIAE) 21:199-208.

Ohu, J. O.; A. Y. Arku and E. Mamman. (2001). Modelling the effect of organic materials incorporated into soils before load application from tractor traffic. Ife Journal of Technology. 10(1) 9-18.

Ohu, J. O.; E. Mamman and M. N. Dammo. (2011). Effect of load application on some physical properties of Firgi Vertisol. Proceedings of the Nigerian Branch of International Soil Tillage Research Organisation ISTRO. 278-290.

Pengthamkeerati, P.; P. P. Motavalli; R. J. Kremer and S. H. Anderson. (2005). Soil carbon dioxide efflux from a claypan soil affected by surface compaction and applications of poultry litter. Agric. Ecosyst. Environ. 109:75-86.

Pengthamkeerati, P.; P. P. Motavalli, R. J. Kremer and S. H. Anderson. (2006). Soil compaction and poultry litter effects on factors affecting nitrogen availability in a claypan soil. Soil Tillage Research 91:109-119.

Radford, B. J.; B. J. Bridge; R. J. Davis; D. McGarry; U. P. Pillai; J. F. Rickman; P. A. Walsh and D. F. Yule. (2000). Changes in the properties of Vertisol and responses of wheat after compaction with harvester traffic. Soil Tillage Research. 54:155-170.

Raper, R. L. and Kirby, J. M. (2006). Soil compaction: How to do it, undo it, or avoid it. In: Agricultural Equipment Technology Conference. Louisville, Kentucky, USA, 1-14.

Reicosky, D. C. (2002). Conservation agriculture: global environmental benefits of soil carbon management. In: 
McKinnon, D., Hamilton-Manns, M. (Eds.), Proceedings of the Monsanto Conservation Agriculture Seminars, New Zealand, 17-25.

Salako F. K.; P. O. Dada; C. O. Adejuyigbe; M. O.
Adedire; O. Martins; C. O. Akwuebu and O. E. Williams. (2007). Soil Strength and Maize yield after Topsoil Removal and Application of Nutrient Amendment on a Gravelly Alfisol Toposequence. Soil Tillage Research 94:21-35. 